\title{
A Method Developed for Determining the Optimum Orientation and the Optimum Shading of School Buildings in Warm Climatic Regions
}

\author{
Simge Eğitmen Varoğlu ${ }^{1 *}$, Müjde Altın ${ }^{2}$ \\ ${ }^{1}$ Faculty of Architecture, Near East University, N. CYPRUS \\ ${ }^{2}$ Faculty of Architecture, Dokuz Eylül University, TURKEY
}

Received 25 September 2017 • Revised 10 October 2017 • Accepted 15 October 2017

\begin{abstract}
The aim of this study is to find optimum angles for the orientation and the shading for buildings in the warm climatic regions. This study was conducted at Cyprus, which has Mediterranean climate. In the literature, many studies exist which consider only optimum orientation or only optimum shading. To this end, this study instead focuses on both optimum orientation and optimum shading and evaluates the results through experimental simulations. This research findings could be used to improve architecture students' skills about optimum orientation and optimum shading for buildings such as school buildings. Further, this study discusses the effective use of sunlight. Different building orientations were tested with a cube building model using the Ecotect simulation software. As a result, the minimum energy consumption area of the total annual energy use (heating and cooling) shows the optimum building orientation. Furthermore, the profile angle, which has the total minimum cooling consumption for the optimum building orientation, demonstrates the optimum shading element angle. In order to find the optimum orientation angle of the cube model, the building was oriented by incrementing $10^{\circ}$ azimuth angle (without shading elements) in the clockwise direction beginning from the north. As a result of the simulation of the cube model, the minimum energy consumption area was found at the azimuth $170^{\circ}$, azimuth $180^{\circ}$ and azimuth $190^{\circ}$. For these orientations, simulations were conducted by incrementing a $1^{\circ}$ azimuth angle between $170^{\circ}$ and $190^{\circ}$. Based on the results of the optimum building orientation, the horizontal shading element was added to the window by incrementing the profile angle from $0^{\circ}$ to $40^{\circ}$ using $10^{\circ}$ step size. Then, an analysis was conducted by increasing $1^{\circ}$ angle for the estimated profile angles that show the minimum energy consumption. The simulation results for the cube model indicates that the optimum profile angle for the horizontal shading element is between $20^{\circ}$ and $30^{\circ}$. As a result, the optimum building orientation for the cube model was determined as azimuth $171^{\circ}$ ( $9^{\circ}$ towards east from the south) and $22^{\circ}$ for the optimum profile angle.
\end{abstract}

Keywords: optimum orientation, optimum shading, profile angle, simulation, minimum energy consumption, architectural education, school buildings

\section{INTRODUCTION}

Due to the different external climatic conditions of thermal conditions in the building, the use of artificial heating and artificial cooling energy in the specific times of year has a significant role in the energy consumption of buildings. The shading elements in the buildings and building orientation are designed in various ways based on the climatic features. Different shading element sizes and building orientations are required for the buildings in different climatic regions in order to utilize the effective sunlight in cold, mild-arid, mild-humid, warm-arid, warm- 


\section{Contribution of this paper to the literature}

- The studies that are separate as building orientation and building shading under the literature are improved with the study conducted for the cube model by adding optimum orientation angle. This study is considered to be useful for the future studies and also education of architecture.

- The aim of this study is to identify the optimum orientation and optimum shading element angle for the buildings located in the warm climate areas.

- It is thought that this study will contribute to the literature and will be useful for students who want to work in this area. As well as the findings could be used for optimum orientation and shading for school buildings and also buildings for different purposes.

humid climates. The aim of this study is to identify the optimum orientation and optimum shading element angle for the buildings located in the warm climate areas. This study was conducted in Cyprus under the Mediterranean climate conditions. Cyprus is within the warm climate zone.

There are several studies in the literature regarding the optimum orientation and optimum shading separately. However, this study analyses the shading elements and building orientation that are discussed separately under the literature, as a whole. The studies given in the literature on the building orientation and shading are summarised as follows.

The Theory of Sol-Air Orientation by A. and V. Olgyay, which is based on the requirement of a person, must be primarily indicated (Olgyay, 1963). Taking the changes in the direct solar radiation realized on the vertical external surface of the building, this method defines the optimum orientation, good and acceptable orientations. The solar radiation of the roof surfaces is avoided under this calculation. This method takes the criteria of "The orientation with maximum solar radiation in the under heated period and the minimum solar radiation in the overheated period is optimal" as a basis and the aim is to provide balanced radiation to the building. The orientations providing approximate values to the solar radiation at optimum orientations are the good orientations. The studies conducted afterwards had defined the orientations with a difference up to $90 \%$ of the solar radiation amount difference in the under heated and overheated periods on the optimum orientations as the good orientations sector, and the orientations with a difference up to $75 \%$ as the Acceptable Orientations sector. The reference surface of building is oriented towards the optimum orientation and the method indicates that the effect of wind in relation with the characteristics of climate zone.

Zeren Method discusses six variables affecting the bioclimatic comfort as efficiency level, thermal insulation value of clothing, dry bulb temperature, relative air speed, relative air humidity and average radiation temperature. It is important to determine the combination among these variables that would provide the most acceptable bioclimatic comfort. The efficiency level and thermal insulation value of clothing can be estimated when the use of space and traditional dressing customs are taken into consideration. The dry bulb temperature, relative air speed, relative air humidity and average radiation temperature constitute the indoor ambient climate elements. Among these four indoor ambient, the dry bulb temperature and subjective relative air speed are important for the heat exchange through body convection. The relative air humidity is vital for the diffusion of water vapour from the skin and the evaporation of sweat from the surface skin. The average radial temperature is identified during the heat exchange via the radiation. Considering the relations among all and building, the Olgyay siblings first discuss the subject of 'building with climate' as a scientific method. Zeren and Berköz developed the deficiencies in this method. Zeren applied the Olgyay Method in the climatic zones of Turkey (Zeren, 1962; Zeren, 1967).

Valko Method aims to identify the variance in the total daily solar radiation loads on all external surfaces of a building, for the cylindrical and rectangular prism shaped buildings, in terms of different orientations and building shapes. This method covering the buildings in the form of cylindrical and rectangular prism was developed for $15^{\text {th }}$ January and 15th July (1973).

Berkoz Method was developed to determine the orientation that would optimise the solar radiation loads for the façade of a building where the most used spaces are located and their roof surfaces in addition to the whole external surface of building for various building forms (Berköz, 1973; Berköz, 1983).

Olgyay \& Olgyay Method is based on the design of shading tools and the method utilises the climatic comfort graph. While the relative humidity values are on the axis of abscissas, the dry bulb temperatures are on the ordinal axis. These values are integrated into the climatic comfort graph and the climatic conditions requiring heating are identified for the related zone. The comfort zone above the shading line does not require any heating, as shading is sufficient for comfort. The shading is not sufficient for the conditions above the shading line and comfort zone; and wind, humidification or sometimes both are needed for being in comfort. The required climatic conditions are presented on a graph with the days in a year and day hours on the coordinates. As a result of processing this zone on a solar orbit diagram that shows the annual track of sun for the specific zone. The steps in the design of Olgyay \& Olgyay shading tool is to identify the annual period not requiring heat gain, the annual and daily shading period 
in terms of space function, the critical solar angles and physical features (number of elements, types, size, surface features) of shading tools (Olgyay and Olgyay, 1957).

Yellot Method was first introduced in 1963. The method discusses the heat gain caused by the solar radiation on the glazing from the transmission, absorption and reflection values of glazing through selecting the required values for the rays in different wave sizes of solar radiation (Yellot, 1963). In 1966, the concept of shading coefficient was introduced in the ASHRAE Guide and Data Book, and the capacity and shading coefficient of single glazing under sun control were determined. Additionally, the total heat gain for single glazing in the summer period was calculated. Consequently, the total heat gains of different glazing types were compared in parallel with the shading coefficient (Yellot, 1966). With further development of method in 1977, the heat gain formulas and several solutions were provided for the areas with and without solar radiation on the glazing (Yellot, 1977).

A study by Givoni noted that the performance of different orientations (generally with windows and the reference façade is oriented to east, west, south and north) was identified on the basis of comparison between internal air and surface temperatures by using single volume models. Moreover, the measurement and comparison of external surface temperatures on the windows facing other directions are also covered under the scope of studies. The trials were performed on the specific days in a year. (Givoni, 1969).

In her PhD thesis called 'A New Method for the Orientation and Design of a Building of Minimal Energy Consumption', Elagöz proposed a method regarding the identification of periods that require heating or cooling for the provinces from climate zones by using energy conservation shading analysis (Elagöz, 1989).

Sun Method elaborates the solar radiation from glazing than the other methods. This method is used to calculate the horizontal shading elements on the finite window and the shaded areas on the windows formed by the vertical shading elements on the edge of window. The variables such as length of window $(\mathrm{L})$, height of window $(\mathrm{H})$, distance between the shading tool and window $(\mathrm{a}, \mathrm{b})$, width of shading tool $(\mathrm{P})$, azimuth and elevation angles of sun, and the azimuth of window are used for the calculation. Lastly, the shaded areas on the window are taken into consideration in the heat gain calculations conducted with the computer program (Sun, 1968).

Rogers et.al. Method is the method that the heating and cooling loads in the buildings are calculated by considering the importance of shading due to the impact of solar radiation, and the results of such calculation are presented via graphs (Rogers, 1978).

Shaviv Method was first introduced in 1978. The window is considered to be divided into small sections, and the positions of sun and solar angles for the desired shade periods were identified. There is a maximum shade length for each hour and 21st day of each month that the shade is desired so that the virtual bars from the centre of each section is at the length of providing shade till the window frame. The numeric values can be converted into graphs (Shaviv, 1978). This method was improved in 1981 and the impact of window orientation on the energy consumption of the buildings. At the times when the heating is wanted and not wanted, the windows were considered as oriented to south, 30 degrees east from south and 30 degrees west from south, and then compared to each other in terms of energy consumption.

Etzion Method is about the design of shading element through utilising the azimuths. This proposed method recommends calculations with graphs in order to proper determination of shading element sizes and forms. The shading tools might be designed on the basis of width, height and orientation of window, and the azimuth and elevation angles of sun (Etzion, 1985). With the improvements in this method by 1992, the shaded and solar areas on the section and plan are identified. With this graphic method, it is possible to calculate the ratio between the section on a window with solar radiation and whole window through the azimuth and elevation angles of sun for the designed shading tool at the related time, the ratio between the width of sunny part on a window and the whole window width, and the ratio between the height of sunny part on a window and whole window height (Etzion, 1992).

Ok Method aims to provide the mathematical interpretation of the shade areas on the vertical shell surfaces of the buildings caused by the other buildings or extensions of buildings themselves. Firstly, the performance needs of settlement density in terms of climatic requirements are identified. Additionally, the relations between the measurement variables like form, location, space, and the settlement density are taken into consideration and various density alternatives were derived (Ok, 1983; Ok, 1992).

It is thought that this study will contribute to the literature and will be useful for students who want to work in this area. As well as the findings could be used for optimum orientation and shading for school buildings and also buildings for different purposes.

Orr (2017) was interested museum, colleque and public school buildings. These buildings reflect the curriculum of the school and reflect the development of the school architecture at the same time.

Carlos (2017) presents results of a study examining ventilation mode, solar heat gain and daylight performance via vertical fenestration of a common school building in Portugal. 
Butera et al. (1985) examine group of school buildings for energy consumption.

Neill and Denham (1982) reflects the pre-school building design, the impact of the building class and the expression of existing child behavior or personnel policy.

A study by Newman and Thomas (2008) it is planned to rebuild all secondary schools under Building Schools for the Future program. One of the requirements of the program is the participation of the student. The aim in this study is to involve students in the design process.

There were several studies indicate with architecture education and education programmes. Kahvecioğlu (2001), discusses many aspects of architecture and design from the systematic and formal unification of architectural education to the forefront of general architectural discussions.

Yücel and Aydinlı (2015), the education of architect includes individual education at the center of the whole for education. Architect, not only in the undergraduate education period, they interacts not only in undergraduate education but in the entire architectural environment, through understanding, inquiry, and transformation of knowledge into this environment. Thus, the education of the architects predicts that, contrary to the idea of architectural education, it can be included in the process of producing social relations and information that can be used in society.

Erzen (1976) reveals that architecture like an education which carried out with an aesthetic environment and the differences from other fileds of science, at architectural education, students must work with all their senses and physique. Otherwise, Erzen (1976) also reported that architectural education improved the talent of comovement of the mind, eye and hand together, and in this way it achives architecture students to had aesthetic perception potential that helps to establish positive and direct relationships with the environment.

On the other hand, Yaşar and Kalfa (2014) had a study about how can the architecture students' educationtraining environment developed.

Another study performed by Nalçakan and Polatoğlu (2008) to investigate comparison of education of architecture in Turkey and World and also influence of globalisation.

Lökçe (2002), architectural education programs, the study areas are expanded by considering various topics such as computer support, energy saving, regional planning, construction development, structure, lighting, heating / cooling under the technology umbrella. For example, the analysis of the relationship between daylight and spaces (windows) is not a computational method but rather a test of the model by a graphical input through the computer.

Besides of this, students educated issues about solar energy, building oriantation and shading elements belong the undergarduate and graduate courses such as "Oriantation in Arhitecture and Solar Control", " Solar Energy and Uses in Architecture", " Integration of Solar Technologies into Architecture", "Energy Problems in Building Design" "Solar Architecture". (DEU,2017; NEU,2017). Researches, had orientation and shading of buildings seperetly at their academic dissertations. (Olgyay, 1963; Zeren, 1962; Zeren, 1967; Berköz, 1973; Berköz, 1983). This research has investigate both orientation and shading of buildings together. We expected that this study will have qualification as a guide for future works.

\section{Purpose}

The research aims to investigate optimum orientation and optimum shading element angle for the buildings located in the warm climate areas such as Mediterranean. The study performed in Cyprus climate zone

\section{METHOD}

In this study, various building orientations were analysed with the Ecotect on a cube model. For the identification of optimum orientation angle in the cube model, the building was oriented by incrementing $10^{\circ}$ azimuth angle in 19 different angle (without shading element) in the clockwise direction beginning from the north (azimuth $0^{\circ}$ ). As a result of simulation results for the cube model, the minimum energy consumption area of the total annual energy use (heating + cooling) was determined as the optimum building orientation. The optimum orientation angle (the minimum annual total heating and cooling energy need) was found by incrementing a $1^{\circ}$ azimuth angle for the identified orientation area of the minimum total annual energy need. Based on the results of the optimum building orientation, the horizontal shading element was added to the window by incrementing the profile angle from $0^{\circ}$ to $40^{\circ}$ using $10^{\circ}$ step size and then an analysis was conducted by increasing $1^{\circ}$ angle for the estimated profile angles that show the minimum annual energy consumption (cooling). The profile angle of the total minimum annual cooling consumption for the optimum orientation determined the optimum shading angle. 


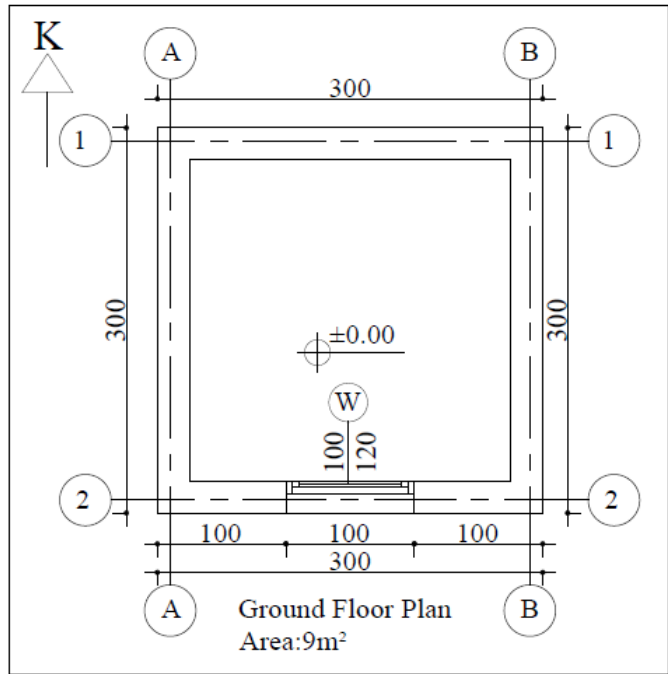

Figure 1. Ground floor plan of cube model

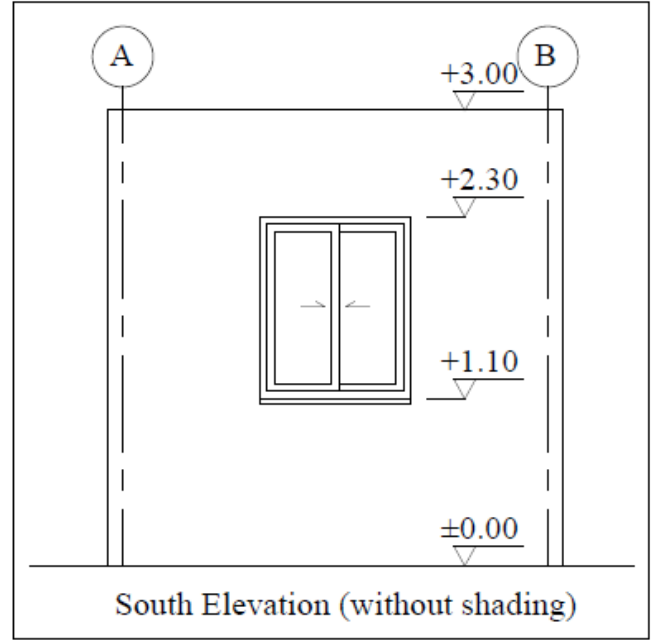

Figure 2. South elevation of cube model (without shading element)

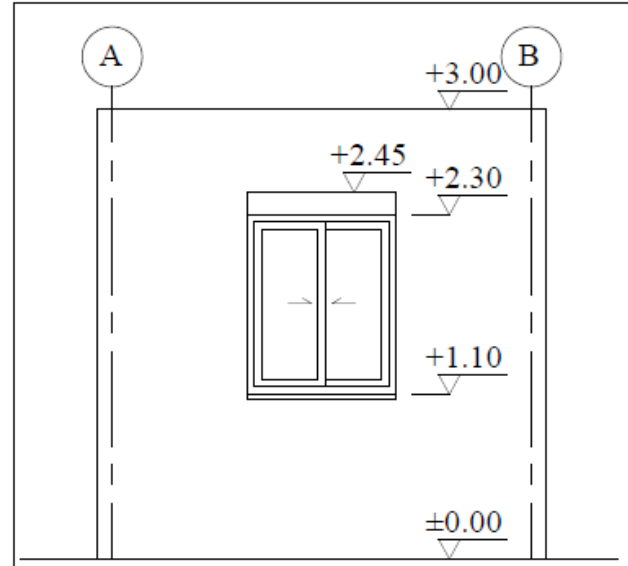

South Elevation (with shading)

Figure 3. South elevation of cube model (with shading element)

\section{FINDINGS}

The study analysed various building orientation on a cube model with $3 \mathrm{~m} \times 3 \mathrm{~m}$ floor area. These analyses were interpreted through the results generated with the Ecotect simulation program from the data such as orientation, 


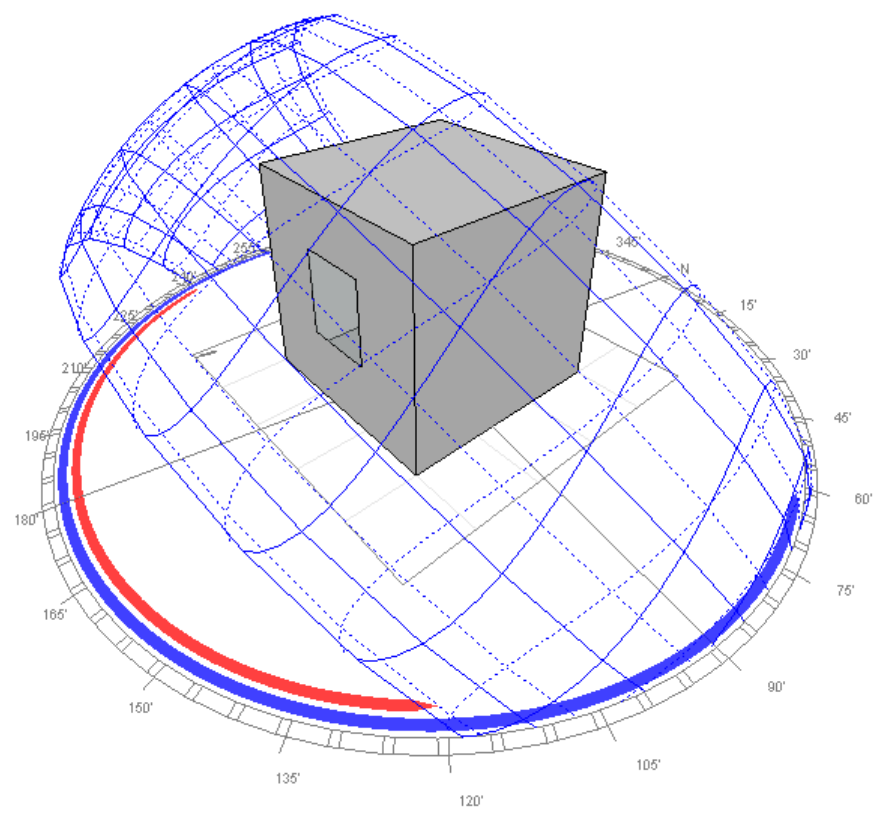

Figure 4. Simulated cube model (without the shading element)

shading element, climate zone. The storey height of cube model is $3 \mathrm{~m}$ with single storey, single window and flat (terrace) roof. There is only one window on the south façade of cube model with the dimensions of $1 \mathrm{~m} \times 1.2 \mathrm{~m}$, single glazing and aluminium frame. The building with reinforced concrete frame is bricked. The brick walls have $11 \mathrm{~cm}$ bricks with $0.1 \mathrm{~cm}$ plaster on both sides of walls (interior/exterior). The material of proposed shading elements is reinforced concrete with the width of $15 \mathrm{~cm}$. The ceiling of building is $15 \mathrm{~cm}$ reinforced concrete and the building is placed on $10 \mathrm{~cm}$ concrete floor.

The cube model was used between 00:00-24:00 and cooling was applied in summer and heating in winter for 7 days and 24 hours. The comfort temperature for the people living in Cyprus was determined as $18^{\circ}-22.1^{\circ} \mathrm{C}$ (Özdeniz, 2013).

For the cube model, heating was applied when the temperature is below $18^{\circ}$ and cooling was applied when the temperature is above $22.1^{\circ} \mathrm{C}$. No heating or cooling was provided when the comfort temperature was available.

\section{Determination of Optimum Orientation Angle}

The objective in the building orientation is to optimise the climate impacts in the provision of comfort conditions and enhance the energy efficiency. Stereographic diagrams are used to represent the varying position of sun throughout day and year. For the cube model, the solar diagram for the angles and orbits with the ground plane related with the latitude in the annual solar motion are given in Figure 4.

The study conducted the simulation for various building orientations in the cube model. Within this framework, firstly the cube model was transferred to the Ecotect program and correlated with sun. 19 different simulations was performed by incrementing $10^{\circ}$ angle between $90^{\circ}$ azimuth angle and $270^{\circ}$ azimuth angle. And then simulations were conducted by incrementing $1^{\circ}$ angle for the area where the annual total energy requirement is minimum. As a result of these simulations, the orientation with the lowest annual total energy (heating+cooling) requirement is the optimum orientation.

\section{Determination of Optimum Shading Angle}

The shading elements, which are a part of the energy efficient design, are a design environment variable controlling the indoor solar radiation based on the desired time in accordance with the positions of windows. The designers should take the shading elements into consideration particularly in the warm climates. The excess heat gain in the warm climates would increase the cooling loads, hence the energy amount for consumption. The shading elements are categorised as vertical, horizontal and mesh (Zeren, 1956). Horizontal shading elements were used for this study. 
EURASIA J Math Sci and Tech Ed

Table 1. Optimum orientation, good and acceptable orientation intervals by the climate zones (Zeren, 1987; Orhon et al., 1988)

\begin{tabular}{|c|c|c|c|c|c|}
\hline \multirow[b]{2}{*}{$\begin{array}{l}\text { Climate } \\
\text { zone }\end{array}$} & \multicolumn{5}{|c|}{ Building Orientation } \\
\hline & Optimum sun direction & $\begin{array}{c}\text { Good orientation } \\
\text { intervals }\end{array}$ & $\begin{array}{c}\text { Acceptable } \\
\text { Orientation intervals }\end{array}$ & $\begin{array}{l}\text { Lay-out direction } \\
\text { by the sun }\end{array}$ & $\begin{array}{c}\text { Protection } \\
\text { from/Utilisation of Wind }\end{array}$ \\
\hline Cold & $\begin{array}{c}\text { Wide surface, } \\
22^{\circ} \text { east from south }\end{array}$ & $\begin{array}{c}20^{\circ} \text { southwest with } \\
45^{\circ} \text { southeast }\end{array}$ & $\begin{array}{c}31^{\circ} \text { southwest with } 86^{\circ} \\
\text { southeast }\end{array}$ & $\begin{array}{c}\text { East-west } \\
\text { axis }\end{array}$ & $\begin{array}{c}\text { Close to wind, Northeast } \\
\text { Southwest axis }\end{array}$ \\
\hline $\begin{array}{l}\text { Mild- } \\
\text { humid }\end{array}$ & $\begin{array}{c}\text { Wide surface, from south } \\
10^{\circ} \text { southeast }\end{array}$ & $\begin{array}{c}13^{\circ} \text { southwest with } \\
35^{\circ} \text { southeast }\end{array}$ & $\begin{array}{c}23^{\circ} \text { southwest with } 49^{\circ} \\
\text { southeast }\end{array}$ & $\begin{array}{l}\text { East-west } \\
\text { axis }\end{array}$ & e to wind \\
\hline Mild-dry & $\begin{array}{c}\text { Wide surface, from south } \\
27^{\circ} \text { southeast } \\
\end{array}$ & $\begin{array}{c}10^{\circ} \text { southwest and } \\
56^{\circ} \text { southeast } \\
\end{array}$ & $\begin{array}{c}14^{\circ} \text { southwest and } 83^{\circ} \\
\text { southeast }\end{array}$ & East-west axis & No space to wind \\
\hline $\begin{array}{l}\text { Warm- } \\
\text { humid }\end{array}$ & $\begin{array}{c}\text { Wide surface, from south } \\
3^{\circ} \text { southeast or north }\end{array}$ & $\begin{array}{c}10^{\circ} \text { southwest and } \\
19^{\circ} \text { southeast }\end{array}$ & $\begin{array}{c}19^{\circ} \text { southwest and } 30^{\circ} \\
\text { southeast }\end{array}$ & axis & $\begin{array}{c}\text { Open to wind, high from } \\
\text { floor }\end{array}$ \\
\hline $\begin{array}{l}\text { Warm- } \\
\text { arid }\end{array}$ & $\begin{array}{l}\text { Wide surface, from } \\
\text { south } 18^{\circ} \text { southeast }\end{array}$ & $\begin{array}{c}0^{\circ} \text { south and } 40^{\circ} \\
\text { southeast }\end{array}$ & $\begin{array}{c}8^{\circ} \text { southwest and } 50^{\circ} \\
\text { southeast }\end{array}$ & $\begin{array}{c}\text { Northwest- } \\
\text { northeast axis }\end{array}$ & $\begin{array}{c}\text { Spaces in yard direction, } \\
\text { yard in north }\end{array}$ \\
\hline
\end{tabular}

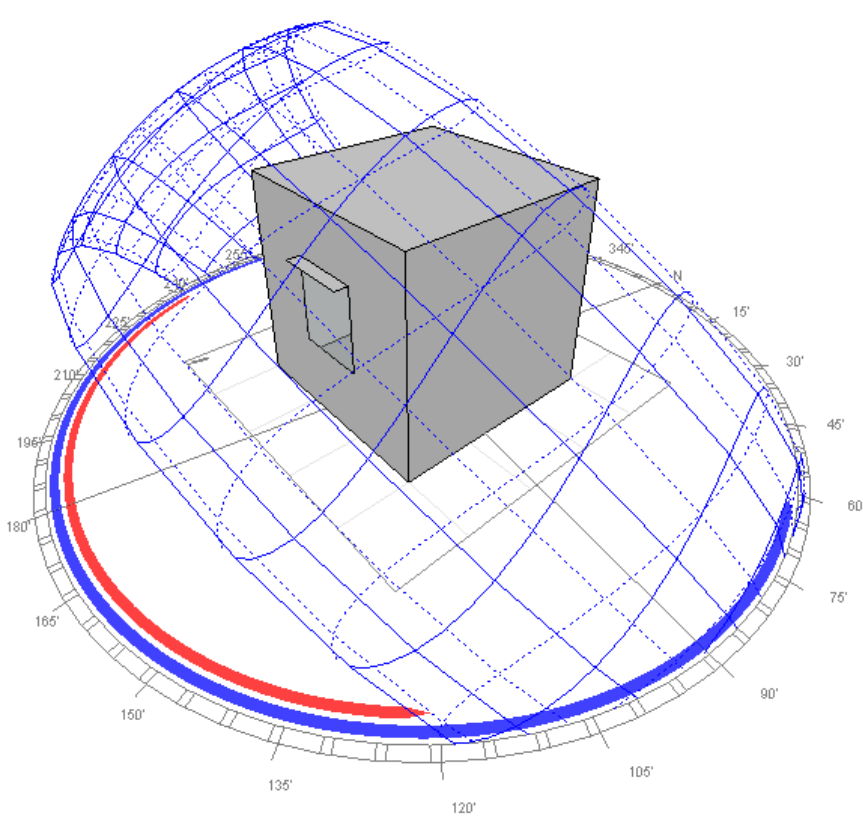

Figure 5. Simulated cube model (with horizontal shading element)

Table 2. Horizontal shading element sizes determined by the profile angles

\begin{tabular}{ccc}
\hline & Shading element profile angle & Shading element length \\
\hline a) & $0^{\circ}$ & - \\
\hline b) & $10^{\circ}$ & $21 \mathrm{~cm}$ \\
\hline c) & $20^{\circ}$ & $44 \mathrm{~cm}$ \\
\hline d) & $30^{\circ}$ & $69 \mathrm{~cm}$ \\
\hline e) & $40^{\circ}$ & $101 \mathrm{~cm}$ \\
\hline
\end{tabular}

Pursuant to the study conducted by Zeren, 1987, Orhonet.al (1988), the optimum orientation, good and acceptable orientation interval based on the climate zones are shown in Table 1.

In this study, a horizontal shading element was designed on the window located on the south façade of cube model (Figure 5). A horizontal shading element was added to the optimum building orientation and to the window; and analyses were conducted by incrementing $10^{\circ}$ profile angle between $0^{\circ}$ and $40^{\circ}$ profile angles, and then by incrementing $1^{\circ}$ profile angle between the profile angles with the minimum energy consumption.

The horizontal shading elements identified by the profile angles in the cube models were given in Table 2 and Figure 6. 


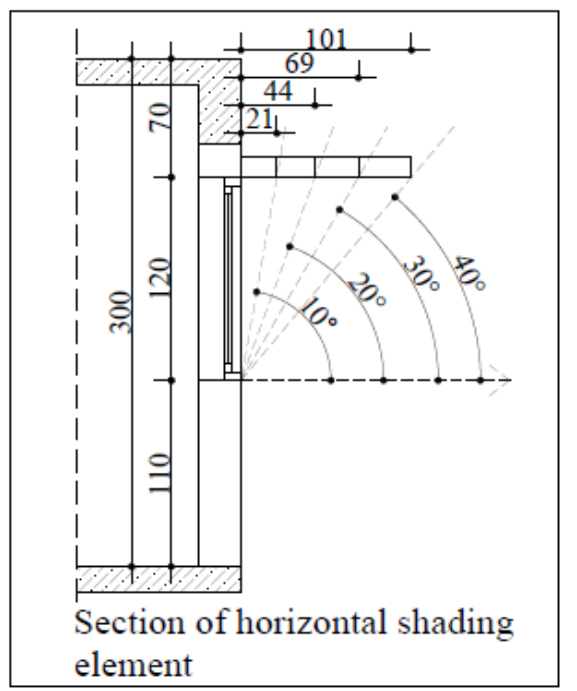

Figure 6. Section of horizontal shading element

Table 3. Ecotest simulation data of cube model

\begin{tabular}{cccc}
\hline Building details & U-Value (W/m2K) & Admittance (W/m2K) & Solar Absorption \\
\hline Brick Plaster (110 mm brick with 10mm plaster either side) & 2.620 & 4.380 & 0.418 \\
\hline Suspended Concrete Ceiling & 2560 & 4.200 & 0.326 \\
\hline Concrete Slab On Ground & 0.880 & 6.000 & 0.467 \\
\hline Single Glazed Aluminium Frame & 6.000 & 6.000 & 0.94 \\
\hline Concrete shading element & 2.560 & 4.200 & 0.326 \\
\hline
\end{tabular}

\section{SIMULATION RESULTS}

The values regarding the materials used in the simulated cube model are given in Table 3 . These information were transferred to the Ecotect simulation program.

In this study, simulations were performed to find the heating, cooling and total energy consumption between $90^{\circ}$ azimuth and $270^{\circ}$ azimuth. Pursuant to the simulation results of cube model, the total energy consumption was first increased between " $90^{\circ}$ azimuth $-160^{\circ}$ azimuth" and " $200^{\circ}$ azimuth - $270^{\circ}$ azimuth" orientation interval and then decreased. The study indicated that the total minimum energy consumption was in $170^{\circ}$ azimuth, $180^{\circ}$ azimuth and $190^{\circ}$ azimuth orientations (Table 4). 
Table 4. The calculation of annual total "heating + cooling" energy consumption by incrementing $10^{\circ}$ azimuth angle to find optimum orientation angle (without shading element)

\begin{tabular}{|c|c|c|c|}
\hline $\begin{array}{l}\text { Profile Angle } \\
\text { Azimuth Angle }\end{array}$ & $0^{\circ}$ & $\begin{array}{l}\text { Profile Angle } \\
\text { Azimuth Angle }\end{array}$ & $0^{\circ}$ \\
\hline Azimuth $90^{\circ}$ & $\begin{array}{c}\text { Heating: } 147216 \mathrm{~W} / \mathrm{m}^{2} \\
\text { Cooling:287018W/m² } \\
\text { Total: } 434234 \mathrm{~W} / \mathrm{m}^{2}\end{array}$ & Azimuth $190^{\circ}$ & $\begin{array}{c}\text { Heating: } 148197 \mathrm{~W} / \mathrm{m}^{2} \\
\text { Cooling: } 285203 \mathrm{~W} / \mathrm{m}^{2} \\
\text { Total: } 433400 \mathrm{~W} / \mathrm{m}^{2}\end{array}$ \\
\hline Azimuth $100^{\circ}$ & $\begin{array}{c}\text { Heating:146351 W/m } \\
\text { Cooling: } 288584 \mathrm{~W} / \mathrm{m}^{2} \\
\text { Total: } 434935 \mathrm{~W} / \mathrm{m}^{2}\end{array}$ & Azimuth $200^{\circ}$ & $\begin{array}{c}\text { Heating:150574 W/m } \\
\text { Cooling:287055 W/m } \\
\text { Total:437630 W/m } \\
\text { T }\end{array}$ \\
\hline Azimuth $110^{\circ}$ & $\begin{array}{c}\text { Heating: } 145670 \mathrm{~W} / \mathrm{m}^{2} \\
\text { Cooling:289935 W/m² } \\
\text { Total: } 435605 \mathrm{~W} / \mathrm{m}^{2}\end{array}$ & Azimuth $210^{\circ}$ & $\begin{array}{c}\text { Heating: } 151840 \mathrm{~W} / \mathrm{m}^{2} \\
\text { Cooling:288303 W/m² } \\
\text { Total: } 440144 \mathrm{~W} / \mathrm{m}^{2}\end{array}$ \\
\hline Azimuth $120^{\circ}$ & $\begin{array}{c}\text { Heating:145326 W/m² } \\
\text { Cooling:290944 W/m² } \\
\text { Total: } 436270 \mathrm{~W} / \mathrm{m}^{2}\end{array}$ & Azimuth $220^{\circ}$ & $\begin{array}{c}\text { Heating:152659 W/m² } \\
\text { Cooling:289194 W/m² } \\
\text { Total: } 441854 \mathrm{~W} / \mathrm{m}^{2}\end{array}$ \\
\hline Azimuth $130^{\circ}$ & $\begin{array}{c}\text { Heating: } 145133 \mathrm{~W} / \mathrm{m}^{2} \\
\text { Cooling: } 291087 \mathrm{~W} / \mathrm{m}^{2} \\
\text { Total: } 436220 \mathrm{~W} / \mathrm{m}^{2}\end{array}$ & Azimuth $230^{\circ}$ & $\begin{array}{c}\text { Heating: } 153140 \mathrm{~W} / \mathrm{m}^{2} \\
\text { Cooling: } 289268 \mathrm{~W} / \mathrm{m}^{2} \\
\text { Total: } 442407 \mathrm{~W} / \mathrm{m}^{2}\end{array}$ \\
\hline Azimuth $140^{\circ}$ & $\begin{array}{c}\text { Heating: } 145155 \mathrm{~W} / \mathrm{m}^{2} \\
\text { Cooling: } 290604 \mathrm{~W} / \mathrm{m}^{2} \\
\text { Total: } 435759 \mathrm{~W} / \mathrm{m}^{2}\end{array}$ & Azimuth $240^{\circ}$ & $\begin{array}{c}\text { Heating: } 153350 \mathrm{~W} / \mathrm{m}^{2} \\
\text { Cooling: } 288800 \mathrm{~W} / \mathrm{m}^{2} \\
\text { Total: } 442149 \mathrm{~W} / \mathrm{m}^{2}\end{array}$ \\
\hline Azimuth $150^{\circ}$ & $\begin{array}{c}\text { Heating: } 145405 \mathrm{~W} / \mathrm{m}^{2} \\
\text { Cooling: } 289278 \mathrm{~W} / \mathrm{m}^{2} \\
\text { Total: } 434683 \mathrm{~W} / \mathrm{m}^{2}\end{array}$ & Azimuth $250^{\circ}$ & $\begin{array}{c}\text { Heating:153469 W/m² } \\
\text { Cooling:287395 W/m² } \\
\text { Total: } 440864 \mathrm{~W} / \mathrm{m}^{2}\end{array}$ \\
\hline Azimuth $160^{\circ}$ & $\begin{array}{c}\text { Heating: } 145936 \mathrm{~W} / \mathrm{m}^{2} \\
\text { Cooling: } 287479 \mathrm{~W} / \mathrm{m}^{2} \\
\text { Total: } 433415 \mathrm{~W} / \mathrm{m}^{2}\end{array}$ & Azimuth $260^{\circ}$ & $\begin{array}{c}\text { Heating:153474 W/m } \\
\text { Cooling:285403 W/m² } \\
\text { Total: } 438877 \mathrm{~W} / \mathrm{m}^{2}\end{array}$ \\
\hline Azimuth $170^{\circ}$ & $\begin{array}{c}\text { Heating: } 146759 \mathrm{~W} / \mathrm{m}^{2} \\
\text { Cooling:285604W/m² } \\
\text { Total:432363 W/m } / \mathrm{m}^{2}\end{array}$ & Azimuth $270^{\circ}$ & $\begin{array}{c}\text { Heating:153663 W/m } \\
\text { Cooling:283637 W/m² } \\
\text { Total: } 437300 \mathrm{~W} / \mathrm{m}^{2}\end{array}$ \\
\hline Azimuth $180^{\circ}$ & $\begin{array}{c}\text { Heating: } 147885 \mathrm{~W} / \mathrm{m}^{2} \\
\text { Cooling: } 285114 \mathrm{~W} / \mathrm{m}^{2} \\
\text { Total:432998 W/m } / \mathrm{m}^{2}\end{array}$ & & \\
\hline
\end{tabular}

Table 5. The calculation of annual total "heating + cooling" energy consumption by incrementing $1^{\circ}$ azimuth angle to find optimum orientation angle

\begin{tabular}{|c|c|c|c|c|c|}
\hline $\begin{array}{r}\text { Energy Need } \\
\text { Azimuth Angle }\end{array}$ & $W / m^{2}$ & $\begin{array}{l}\text { Energy Need } \\
\text { Azimuth Angle }\end{array}$ & $W / m^{2}$ & $\begin{array}{l}\text { Energy Need } \\
\text { Azimuth Angle }\end{array}$ & $W / m^{2}$ \\
\hline \multirow{3}{*}{ Azimuth $170^{\circ}$} & Heating:146759 & & Heating:147527 & & Heating:148352 \\
\hline & Cooling:285604 & Azimuth $177^{\circ}$ & Cooling:285100 & Azimuth $184^{\circ}$ & Cooling:285071 \\
\hline & Total:432363 & & Total:432627 & & Total:433423 \\
\hline \multirow{3}{*}{ Azimuth $171^{\circ}$} & Heating:14685 & & Heating:147607 & & Heating:148522 \\
\hline & Cooling:28546 & Azimuth $178^{\circ}$ & Cooling:285217 & Azimuth $185^{\circ}$ & Cooling:285099 \\
\hline & Total:432328 & & Total:432823 & & Total:433621 \\
\hline \multirow{3}{*}{ Azimuth $172^{\circ}$} & Heating:146957 & & Heating:147722 & & Heating:148647 \\
\hline & Cooling:285400 & Azimuth $179^{\circ}$ & Cooling:285165 & Azimuth $186^{\circ}$ & Cooling:285138 \\
\hline & Total:432357 & & Total:432887 & & Total:433785 \\
\hline \multirow{3}{*}{ Azimuth $173^{\circ}$} & Heating:147056 & & Heating:147885 & & Heating:148767 \\
\hline & Cooling:285283 & Azimuth $180^{\circ}$ & Cooling:285114 & Azimuth $187^{\circ}$ & Cooling:285152 \\
\hline & Total:432339 & & Total:432998 & & Total:433919 \\
\hline \multirow{3}{*}{ Azimuth $174^{\circ}$} & Heating:147162 & & Heating:148001 & & Heating:148881 \\
\hline & Cooling:285198 & Azimuth $181^{\circ}$ & Cooling:285094 & Azimuth $188^{\circ}$ & Cooling:285388 \\
\hline & Total:432359 & & Total:433095 & & Total:434269 \\
\hline \multirow{3}{*}{ Azimuth $175^{\circ}$} & Heating:147302 & & Heating:148121 & & Heating:149017 \\
\hline & Cooling:285160 & Azimuth $182^{\circ}$ & Cooling:285082 & Azimuth $189^{\circ}$ & Cooling:285420 \\
\hline & Total:432462 & & Total:433203 & & Total:434438 \\
\hline \multirow{3}{*}{ Azimuth $176^{\circ}$} & Heating:147415 & & Heating:148231 & & Heating:148197 \\
\hline & Cooling:285175 & Azimuth $183^{\circ}$ & Cooling:285182 & Azimuth $190^{\circ}$ & Cooling:285203 \\
\hline & Total:432591 & & Total:433413 & & Total:433400 \\
\hline
\end{tabular}

For the generated optimum orientation interval, the simulations were conducted by incrementing $1^{\circ}$ azimuth angle. The simulation results were shown in Table 5.

In consideration with the simulation results conducted on the cube model by incrementing $1^{\circ}$ angle, the minimum energy consumption was identified as $171^{\circ}$ azimuth. For this optimum orientation, the simulation results by incrementing $10^{\circ}$ profile angle with an addition of horizontal shading element between $0^{\circ}-40^{\circ}$ are given in Table 6. 
Table 6. The calculation of annual total "heating + cooling" energy consumption by incrementing $1^{\circ}$ azimuth angle between $170^{\circ}$ azimuth $190^{\circ}$ azimuth with an addition of horizontal shading element between $0^{\circ}-40^{\circ}$ to find optimum orientation angle

\begin{tabular}{|c|c|c|c|c|c|}
\hline $\begin{array}{r}\text { Profile Angle } \\
\text { Azimuth Angle }\end{array}$ & $0^{\circ}$ & $10^{\circ}(21 \mathrm{~cm})$ & $20^{\circ}(44 \mathrm{~cm})$ & $30^{\circ}(69 \mathrm{~cm})$ & $40^{\circ}(101 \mathrm{~cm})$ \\
\hline \multirow{3}{*}{ Azimuth $170^{\circ}$} & $\mathrm{H}: 146759 \mathrm{~W} / \mathrm{m}^{2}$ & $\mathrm{H}: 147754 \mathrm{~W} / \mathrm{m}^{2}$ & $\mathrm{H}: 148814 \mathrm{~W} / \mathrm{m}^{2}$ & $\mathrm{H}: 149775 \mathrm{~W} / \mathrm{m}^{2}$ & $\mathrm{~T}: 151062 \mathrm{~W} / \mathrm{m}^{2}$ \\
\hline & $\mathrm{C}: 285604 \mathrm{~W} / \mathrm{m}^{2}$ & $\mathrm{C}: 285340 \mathrm{~W} / \mathrm{m}^{2}$ & $\mathrm{C}: 285320 \mathrm{~W} / \mathrm{m}^{2}$ & $\mathrm{C}: 285243 \mathrm{~W} / \mathrm{m}^{2}$ & $\mathrm{C}: 285750 \mathrm{~W} / \mathrm{m}^{2}$ \\
\hline & $\mathrm{T}: 432363 \mathrm{~W} / \mathrm{m}^{2}$ & $\mathrm{~T}: 433094 \mathrm{~W} / \mathrm{m}^{2}$ & $\mathrm{~T}: 434134 \mathrm{~W} / \mathrm{m}^{2}$ & $\mathrm{~T}: 435018 \mathrm{~W} / \mathrm{m}^{2}$ & $\mathrm{~T}: 436812 \mathrm{~W} / \mathrm{m}^{2}$ \\
\hline \multirow{3}{*}{ Azimuth $171^{\circ}$} & $\mathrm{H}: 146859 \mathrm{~W} / \mathrm{m}^{2}$ & $\mathrm{H}: 147854 \mathrm{~W} / \mathrm{m}^{2}$ & $\mathrm{H}: 148892 \mathrm{~W} / \mathrm{m}^{2}$ & $\mathrm{H}: 149875 \mathrm{~W} / \mathrm{m}^{2}$ & $\mathrm{H}: 151141 \mathrm{~W} / \mathrm{m}^{2}$ \\
\hline & $\mathrm{C}: 285468 \mathrm{~W} / \mathrm{m}^{2}$ & $\mathrm{C}: 285205 \mathrm{~W} / \mathrm{m}^{2}$ & $\mathrm{C}: 285008 \mathrm{~W} / \mathrm{m}^{2}$ & $\mathrm{C}: 285159 \mathrm{~W} / \mathrm{m}^{2}$ & $\mathrm{C}: 285615 \mathrm{~W} / \mathrm{m}^{2}$ \\
\hline & $\mathrm{T}: 432328 \mathrm{~W} / \mathrm{m}^{2}$ & $\mathrm{~T}: 433058 \mathrm{~W} / \mathrm{m}^{2}$ & $\mathrm{~T}: 433900 \mathrm{~W} / \mathrm{m}^{2}$ & $\mathrm{~T}: 435034 \mathrm{~W} / \mathrm{m}^{2}$ & $\mathrm{~T}: 436756 \mathrm{~W} / \mathrm{m}^{2}$ \\
\hline \multirow{3}{*}{ Azimuth $172^{\circ}$} & $\mathrm{H}: 146957 \mathrm{~W} / \mathrm{m}^{2}$ & $\mathrm{H}: 147917 \mathrm{~W} / \mathrm{m}^{2}$ & $\mathrm{H}: 148991 \mathrm{~W} / \mathrm{m}^{2}$ & $\mathrm{H}: 149973 \mathrm{~W} / \mathrm{m}^{2}$ & $\mathrm{H}: 151239 \mathrm{~W} / \mathrm{m}^{2}$ \\
\hline & $\mathrm{C}: 285400 \mathrm{~W} / \mathrm{m}^{2}$ & $\mathrm{C}: 285136 \mathrm{~W} / \mathrm{m}^{2}$ & $\mathrm{C}: 285035 \mathrm{~W} / \mathrm{m}^{2}$ & $\mathrm{C}: 285056 \mathrm{~W} / \mathrm{m}^{2}$ & $\mathrm{C}: 285566 \mathrm{~W} / \mathrm{m}^{2}$ \\
\hline & $\mathrm{T}: 432357 \mathrm{~W} / \mathrm{m}^{2}$ & $\mathrm{~T}: 433052 \mathrm{~W} / \mathrm{m}^{2}$ & $\mathrm{~T}: 434025 \mathrm{~W} / \mathrm{m}^{2}$ & $\mathrm{~T}: 435029 \mathrm{~W} / \mathrm{m}^{2}$ & $\mathrm{~T}: 436805 \mathrm{~W} / \mathrm{m}^{2}$ \\
\hline \multirow{3}{*}{ Azimuth $173^{\circ}$} & $\mathrm{H}: 147056 \mathrm{~W} / \mathrm{m}^{2}$ & $\mathrm{H}: 148029 \mathrm{~W} / \mathrm{m}^{2}$ & $\mathrm{H}: 149089 \mathrm{~W} / \mathrm{m}^{2}$ & $\mathrm{H}: 150071 \mathrm{~W} / \mathrm{m}^{2}$ & $\mathrm{H}: 151337 \mathrm{~W} / \mathrm{m}^{2}$ \\
\hline & $\mathrm{C}: 285283 \mathrm{~W} / \mathrm{m}^{2}$ & $\mathrm{C}: 285019 \mathrm{~W} / \mathrm{m}^{2}$ & $\mathrm{C}: 284857 \mathrm{~W} / \mathrm{m}^{2}$ & $\mathrm{C}: 284924 \mathrm{~W} / \mathrm{m}^{2}$ & $\mathrm{C}: 285434 \mathrm{~W} / \mathrm{m}^{2}$ \\
\hline & $\mathrm{T}: 432339 \mathrm{~W} / \mathrm{m}^{2}$ & $\mathrm{~T}: 43304 \mathrm{~W} / \mathrm{m}^{2}$ & $\mathrm{~T}: 433946 \mathrm{~W} / \mathrm{m}^{2}$ & $\mathrm{~T}: 434995 \mathrm{~W} / \mathrm{m}^{2}$ & $\mathrm{~T}: 436772 \mathrm{~W} / \mathrm{m}^{2}$ \\
\hline \multirow{3}{*}{ Azimuth $174^{\circ}$} & $\mathrm{H}: 147162 \mathrm{~W} / \mathrm{m}^{2}$ & $\mathrm{H}: 148101 \mathrm{~W} / \mathrm{m}^{2}$ & $\mathrm{H}: 149196 \mathrm{~W} / \mathrm{m}^{2}$ & $\mathrm{H}: 150179 \mathrm{~W} / \mathrm{m}^{2}$ & $\mathrm{H}: 151445 \mathrm{~W} / \mathrm{m}^{2}$ \\
\hline & C: $285198 \mathrm{~W} / \mathrm{m}^{2}$ & $\mathrm{C}: 284937 \mathrm{~W} / \mathrm{m}^{2}$ & $\mathrm{C}: 284775 \mathrm{~W} / \mathrm{m}^{2}$ & $\mathrm{C}: 284877 \mathrm{~W} / \mathrm{m}^{2}$ & $\mathrm{C}: 285312 \mathrm{~W} / \mathrm{m}^{2}$ \\
\hline & $\mathrm{T}: 432359 \mathrm{~W} / \mathrm{m}^{2}$ & $\mathrm{~T}: 433038 \mathrm{~W} / \mathrm{m}^{2}$ & $\mathrm{~T}: 433971 \mathrm{~W} / \mathrm{m}^{2}$ & $\mathrm{~T}: 435056 \mathrm{~W} / \mathrm{m}^{2}$ & $\mathrm{~T}: 436758 \mathrm{~W} / \mathrm{m}^{2}$ \\
\hline \multirow{3}{*}{ Azimuth $175^{\circ}$} & $\mathrm{H}: 147302 \mathrm{~W} / \mathrm{m}^{2}$ & $\mathrm{H}: 148242 \mathrm{~W} / \mathrm{m}^{2}$ & $\mathrm{H}: 149337 \mathrm{~W} / \mathrm{m}^{2}$ & $\mathrm{H}: 150320 \mathrm{~W} / \mathrm{m}^{2}$ & $\mathrm{H}: 151586 \mathrm{~W} / \mathrm{m}^{2}$ \\
\hline & $\mathrm{C}: 285160 \mathrm{~W} / \mathrm{m}^{2}$ & $\mathrm{C}: 284896 \mathrm{~W} / \mathrm{m}^{2}$ & $\mathrm{C}: 284734 \mathrm{~W} / \mathrm{m}^{2}$ & $\mathrm{C}: 284761 \mathrm{~W} / \mathrm{m}^{2}$ & $\mathrm{C}: 285250 \mathrm{~W} / \mathrm{m}^{2}$ \\
\hline & $\mathrm{T}: 432462 \mathrm{~W} / \mathrm{m}^{2}$ & $\mathrm{~T}: 433138 \mathrm{~W} / \mathrm{m}^{2}$ & $434071 \mathrm{~W} / \mathrm{m}^{2}$ & $435080 \mathrm{~W} / \mathrm{m}^{2}$ & $436837 \mathrm{~W} / \mathrm{m}^{2}$ \\
\hline \multirow{3}{*}{ Azimuth $176^{\circ}$} & $\mathrm{H}: 147415 \mathrm{~W} / \mathrm{m}^{2}$ & $\mathrm{H}: 148356 \mathrm{~W} / \mathrm{m}^{2}$ & $\mathrm{H}: 149451 \mathrm{~W} / \mathrm{m}^{2}$ & $\mathrm{H}: 150434 \mathrm{~W} / \mathrm{m}^{2}$ & $\mathrm{H}: 151700 \mathrm{~W} / \mathrm{m}^{2}$ \\
\hline & $\mathrm{C}: 285175 \mathrm{~W} / \mathrm{m}^{2}$ & $\mathrm{C}: 284911 \mathrm{~W} / \mathrm{m}^{2}$ & $\mathrm{C}: 284601 \mathrm{~W} / \mathrm{m}^{2}$ & $\mathrm{C}: 284704 \mathrm{~W} / \mathrm{m}^{2}$ & $\mathrm{C}: 285177 \mathrm{~W} / \mathrm{m}^{2}$ \\
\hline & $\mathrm{T}: 432591 \mathrm{~W} / \mathrm{m}^{2}$ & $\mathrm{~T}: 433266 \mathrm{~W} / \mathrm{m}^{2}$ & $\mathrm{~T}: 434052 \mathrm{~W} / \mathrm{m}^{2}$ & $\mathrm{~T}: 435137 \mathrm{~W} / \mathrm{m}^{2}$ & $\mathrm{~T}: 436877 \mathrm{~W} / \mathrm{m}^{2}$ \\
\hline \multirow{3}{*}{ Azimuth $177^{\circ}$} & $\mathrm{H}: 147527 \mathrm{~W} / \mathrm{m}^{2}$ & $\mathrm{H}: 148467 \mathrm{~W} / \mathrm{m}^{2}$ & $\mathrm{H}: 149563 \mathrm{~W} / \mathrm{m}^{2}$ & $\mathrm{H}: 150545 \mathrm{~W} / \mathrm{m}^{2}$ & $\mathrm{H}: 151812 \mathrm{~W} / \mathrm{m}^{2}$ \\
\hline & $\mathrm{C}: 285100 \mathrm{~W} / \mathrm{m}^{2}$ & $\mathrm{C}: 284836 \mathrm{~W} / \mathrm{m}^{2}$ & $\mathrm{C}: 284724 \mathrm{~W} / \mathrm{m}^{2}$ & $\mathrm{C}: 284737 \mathrm{~W} / \mathrm{m}^{2}$ & $\mathrm{C}: 285168 \mathrm{~W} / \mathrm{m}^{2}$ \\
\hline & $\mathrm{T}: 432627 \mathrm{~W} / \mathrm{m}^{2}$ & $\mathrm{~T}: 433303 \mathrm{~W} / \mathrm{m}^{2}$ & $\mathrm{~T}: 434287 \mathrm{~W} / \mathrm{m}^{2}$ & $\mathrm{~T}: 435282 \mathrm{~W} / \mathrm{m}^{2}$ & $\mathrm{~T}: 436980 \mathrm{~W} / \mathrm{m}^{2}$ \\
\hline \multirow{3}{*}{ Azimuth $178^{\circ}$} & $\mathrm{H}: 147607 \mathrm{~W} / \mathrm{m}^{2}$ & $\mathrm{H}: 148567 \mathrm{~W} / \mathrm{m}^{2}$ & $\mathrm{H}: 149627 \mathrm{~W} / \mathrm{m}^{2}$ & $\mathrm{H}: 150645 \mathrm{~W} / \mathrm{m}^{2}$ & $\mathrm{H}: 151912 \mathrm{~W} / \mathrm{m}^{2}$ \\
\hline & $\mathrm{C}: 285217 \mathrm{~W} / \mathrm{m}^{2}$ & $\mathrm{C}: 284952 \mathrm{~W} / \mathrm{m}^{2}$ & $\mathrm{C}: 284775 \mathrm{~W} / \mathrm{m}^{2}$ & $\mathrm{C}: 284842 \mathrm{~W} / \mathrm{m}^{2}$ & $\mathrm{C}: 285224 \mathrm{~W} / \mathrm{m}^{2}$ \\
\hline & $\mathrm{T}: 432823 \mathrm{~W} / \mathrm{m}^{2}$ & $\mathrm{~T}: 433519 \mathrm{~W} / \mathrm{m}^{2}$ & $434402 \mathrm{~W} / \mathrm{m}^{2}$ & $\mathrm{~T}: 435487 \mathrm{~W} / \mathrm{m}^{2}$ & $\mathrm{~T}: 437136 \mathrm{~W} / \mathrm{m}^{2}$ \\
\hline \multirow{3}{*}{ Azimuth $179^{\circ}$} & $\mathrm{H}: 147722 \mathrm{~W} / \mathrm{m}^{2}$ & $\mathrm{H}: 148683 \mathrm{~W} / \mathrm{m}^{2}$ & $\mathrm{H}: 149743 \mathrm{~W} / \mathrm{m}^{2}$ & $\mathrm{H}: 150761 \mathrm{~W} / \mathrm{m}^{2}$ & $\mathrm{H}: 152029 \mathrm{~W} / \mathrm{m}^{2}$ \\
\hline & $\mathrm{C}: 285165 \mathrm{~W} / \mathrm{m}^{2}$ & $\mathrm{C}: 284860 \mathrm{~W} / \mathrm{m}^{2}$ & $\mathrm{C}: 284683 \mathrm{~W} / \mathrm{m}^{2}$ & $\mathrm{C}: 284710 \mathrm{~W} / \mathrm{m}^{2}$ & C: $285148 \mathrm{~W} / \mathrm{m}^{2}$ \\
\hline & $\mathrm{T}: 432887 \mathrm{~W} / \mathrm{m}^{2}$ & $\mathrm{~T}: 433543 \mathrm{~W} / \mathrm{m}^{2}$ & $\mathrm{~T}: 434426 \mathrm{~W} / \mathrm{m}^{2}$ & $\mathrm{~T}: 43547 \mathrm{~W} / \mathrm{m}^{2}$ & $\mathrm{~T}: 437177 \mathrm{~W} / \mathrm{m}^{2}$ \\
\hline \multirow{3}{*}{ Azimuth $180^{\circ}$} & $\mathrm{H}: 147885 \mathrm{~W} / \mathrm{m}^{2}$ & $\mathrm{H}: 148845 \mathrm{~W} / \mathrm{m}^{2}$ & $\mathrm{H}: 149906 \mathrm{~W} / \mathrm{m}^{2}$ & $\mathrm{H}: 150924 \mathrm{~W} / \mathrm{m}^{2}$ & $\mathrm{H}: 152192 \mathrm{~W} / \mathrm{m}^{2}$ \\
\hline & $\mathrm{C}: 285114 \mathrm{~W} / \mathrm{m}^{2}$ & $\mathrm{C}: 284688 \mathrm{~W} / \mathrm{m}^{2}$ & $\mathrm{C}: 284536 \mathrm{~W} / \mathrm{m}^{2}$ & $\mathrm{C}: 284679 \mathrm{~W} / \mathrm{m}^{2}$ & $\mathrm{C}: 285134 \mathrm{~W} / \mathrm{m}^{2}$ \\
\hline & $\mathrm{T}: 432998 \mathrm{~W} / \mathrm{m}^{2}$ & $\mathrm{~T}: 433533 \mathrm{~W} / \mathrm{m}^{2}$ & $\mathrm{~T}: 434441 \mathrm{~W} / \mathrm{m}^{2}$ & $\mathrm{~T}: 435603 \mathrm{~W} / \mathrm{m}^{2}$ & $\mathrm{~T}: 437326 \mathrm{~W} / \mathrm{m}^{2}$ \\
\hline \multirow{3}{*}{ Azimuth $181^{\circ}$} & $\mathrm{H}: 148001 \mathrm{~W} / \mathrm{m}^{2}$ & $\mathrm{H}: 148962 \mathrm{~W} / \mathrm{m}^{2}$ & $\mathrm{H}: 150022 \mathrm{~W} / \mathrm{m}^{2}$ & $\mathrm{H}: 151041 \mathrm{~W} / \mathrm{m}^{2}$ & $\mathrm{H}: 152309 \mathrm{~W} / \mathrm{m}^{2}$ \\
\hline & $\mathrm{C}: 285094 \mathrm{~W} / \mathrm{m}^{2}$ & $\mathrm{C}: 284672 \mathrm{~W} / \mathrm{m}^{2}$ & $\mathrm{C}: 284560 \mathrm{~W} / \mathrm{m}^{2}$ & $\mathrm{C}: 284663 \mathrm{~W} / \mathrm{m}^{2}$ & $\mathrm{C}: 285170 \mathrm{~W} / \mathrm{m}^{2}$ \\
\hline & $\mathrm{T}: 433095 \mathrm{~W} / \mathrm{m}^{2}$ & $\mathrm{~T}: 433634 \mathrm{~W} / \mathrm{m}^{2}$ & $\mathrm{~T}: 434582 \mathrm{~W} / \mathrm{m}^{2}$ & $\mathrm{~T}: 435703 \mathrm{~W} / \mathrm{m}^{2}$ & $\mathrm{~T}: 437479 \mathrm{~W} / \mathrm{m}^{2}$ \\
\hline \multirow{3}{*}{ Azimuth $182^{\circ}$} & $\mathrm{H}: 148121 \mathrm{~W} / \mathrm{m}^{2}$ & $\mathrm{H}: 149082 \mathrm{~W} / \mathrm{m}^{2}$ & $\mathrm{H}: 150144 \mathrm{~W} / \mathrm{m}^{2}$ & $\mathrm{H}: 151163 \mathrm{~W} / \mathrm{m}^{2}$ & $\mathrm{H}: 152432 \mathrm{~W} / \mathrm{m}^{2}$ \\
\hline & $\mathrm{C}: 285082 \mathrm{~W} / \mathrm{m}^{2}$ & $\mathrm{C}: 284678 \mathrm{~W} / \mathrm{m}^{2}$ & $\mathrm{C}: 284580 \mathrm{~W} / \mathrm{m}^{2}$ & $\mathrm{C}: 284628 \mathrm{~W} / \mathrm{m}^{2}$ & $\mathrm{C}: 285020 \mathrm{~W} / \mathrm{m}^{2}$ \\
\hline & $\mathrm{T}: 433203 \mathrm{~W} / \mathrm{m}^{2}$ & $\mathrm{~T}: 433760 \mathrm{~W} / \mathrm{m}^{2}$ & $\mathrm{~T}: 434724 \mathrm{~W} / \mathrm{m}^{2}$ & $\mathrm{~T}: 435791 \mathrm{~W} / \mathrm{m}^{2}$ & $\mathrm{~T}: 437453 \mathrm{~W} / \mathrm{m}^{2}$ \\
\hline \multirow{3}{*}{ Azimuth $183^{\circ}$} & $\mathrm{H}: 148231 \mathrm{~W} / \mathrm{m}^{2}$ & $\mathrm{H}: 149192 \mathrm{~W} / \mathrm{m}^{2}$ & $\mathrm{H}: 150253 \mathrm{~W} / \mathrm{m}^{2}$ & $\mathrm{H}: 151272 \mathrm{~W} / \mathrm{m}^{2}$ & $\mathrm{H}: 152542 \mathrm{~W} / \mathrm{m}^{2}$ \\
\hline & $\mathrm{C}: 285182 \mathrm{~W} / \mathrm{m}^{2}$ & $\mathrm{C}: 284902 \mathrm{~W} / \mathrm{m}^{2}$ & $\mathrm{C}: 284762 \mathrm{~W} / \mathrm{m}^{2}$ & $\mathrm{C}: 284813 \mathrm{~W} / \mathrm{m}^{2}$ & $\mathrm{C}: 285090 \mathrm{~W} / \mathrm{m}^{2}$ \\
\hline & $\mathrm{T}: 433413 \mathrm{~W} / \mathrm{m}^{2}$ & $\mathrm{~T}: 434094 \mathrm{~W} / \mathrm{m}^{2}$ & $\mathrm{~T}: 435016 \mathrm{~W} / \mathrm{m}^{2}$ & $\mathrm{~T}: 436085 \mathrm{~W} / \mathrm{m}^{2}$ & $\mathrm{~T}: 437632 \mathrm{~W} / \mathrm{m}^{2}$ \\
\hline & $\mathrm{H}: 148352 \mathrm{~W} / \mathrm{m}^{2}$ & $\mathrm{H}: 149313 \mathrm{~W} / \mathrm{m}^{2}$ & $\mathrm{H}: 150375 \mathrm{~W} / \mathrm{m}^{2}$ & $\mathrm{H}: 151395 \mathrm{~W} / \mathrm{m}^{2}$ & $\mathrm{H}: 152666 \mathrm{~W} / \mathrm{m}^{2}$ \\
\hline Azimuth $184^{\circ}$ & $\mathrm{C}: 285071 \mathrm{~W} / \mathrm{m}^{2}$ & $\mathrm{C}: 284807 \mathrm{~W} / \mathrm{m}^{2}$ & $\mathrm{C}: 284767 \mathrm{~W} / \mathrm{m}^{2}$ & $\mathrm{C}: 284752 \mathrm{~W} / \mathrm{m}^{2}$ & $\mathrm{C}: 285030 \mathrm{~W} / \mathrm{m}^{2}$ \\
\hline & $\mathrm{T}: 433423 \mathrm{~W} / \mathrm{m}^{2}$ & $\mathrm{~T}: 434120 \mathrm{~W} / \mathrm{m}^{2}$ & $\mathrm{~T}: 435143 \mathrm{~W} / \mathrm{m}^{2}$ & $\mathrm{~T}: 436148 \mathrm{~W} / \mathrm{m}^{2}$ & $\mathrm{~T}: 437696 \mathrm{~W} / \mathrm{m}^{2}$ \\
\hline & $\mathrm{H}: 148522 \mathrm{~W} / \mathrm{m}^{2}$ & $\mathrm{H}: 149484 \mathrm{~W} / \mathrm{m}^{2}$ & $\mathrm{H}: 150546 \mathrm{~W} / \mathrm{m}^{2}$ & $\mathrm{H}: 151566 \mathrm{~W} / \mathrm{m}^{2}$ & $\mathrm{H}: 152838 \mathrm{~W} / \mathrm{m}^{2}$ \\
\hline Azimuth $185^{\circ}$ & $\mathrm{C}: 285099 \mathrm{~W} / \mathrm{m}^{2}$ & $\mathrm{C}: 284741 \mathrm{~W} / \mathrm{m}^{2}$ & $\mathrm{C}: 284702 \mathrm{~W} / \mathrm{m}^{2}$ & $\mathrm{C}: 284644 \mathrm{~W} / \mathrm{m}^{2}$ & $\mathrm{C}: 285006 \mathrm{~W} / \mathrm{m}^{2}$ \\
\hline & $\mathrm{T}: 433621 \mathrm{~W} / \mathrm{m}^{2}$ & $\mathrm{~T}: 434225 \mathrm{~W} / \mathrm{m}^{2}$ & $\mathrm{~T}: 435248 \mathrm{~W} / \mathrm{m}^{2}$ & $\mathrm{~T}: 436211 \mathrm{~W} / \mathrm{m}^{2}$ & $\mathrm{~T}: 437843 \mathrm{~W} / \mathrm{m}^{2}$ \\
\hline & $\mathrm{H}: 148647 \mathrm{~W} / \mathrm{m}^{2}$ & $\mathrm{H}: 149609 \mathrm{~W} / \mathrm{m}^{2}$ & $\mathrm{H}: 150671 \mathrm{~W} / \mathrm{m}^{2}$ & $\mathrm{H}: 151655 \mathrm{~W} / \mathrm{m}^{2}$ & $\mathrm{H}: 152963 \mathrm{~W} / \mathrm{m}^{2}$ \\
\hline Azimuth $186^{\circ}$ & $\mathrm{C}: 285138 \mathrm{~W} / \mathrm{m}^{2}$ & $\mathrm{C}: 284792 \mathrm{~W} / \mathrm{m}^{2}$ & $\mathrm{C}: 284678 \mathrm{~W} / \mathrm{m}^{2}$ & $\mathrm{C}: 284550 \mathrm{~W} / \mathrm{m}^{2}$ & $\mathrm{C}: 285048 \mathrm{~W} / \mathrm{m}^{2}$ \\
\hline & $\mathrm{T}: 433785 \mathrm{~W} / \mathrm{m}^{2}$ & $\mathrm{~T}: 434400 \mathrm{~W} / \mathrm{m}^{2}$ & $\mathrm{~T}: 435349 \mathrm{~W} / \mathrm{m}^{2}$ & $\mathrm{~T}: 436206 \mathrm{~W} / \mathrm{m}^{2}$ & $\mathrm{~T}: 438011 \mathrm{~W} / \mathrm{m}^{2}$ \\
\hline & $\mathrm{H}: 148767 \mathrm{~W} / \mathrm{m}^{2}$ & $\mathrm{H}: 149730 \mathrm{~W} / \mathrm{m}^{2}$ & $\mathrm{H}: 150793 \mathrm{~W} / \mathrm{m}^{2}$ & $\mathrm{H}: 151778 \mathrm{~W} / \mathrm{m}^{2}$ & $\mathrm{H}: 153087 \mathrm{~W} / \mathrm{m}^{2}$ \\
\hline Azimuth $187^{\circ}$ & C: $285152 \mathrm{~W} / \mathrm{m}^{2}$ & C:284889W/m² & $\mathrm{C}: 284775 \mathrm{~W} / \mathrm{m}^{2}$ & $\mathrm{C}: 284772 \mathrm{~W} / \mathrm{m}^{2}$ & $\mathrm{C}: 285144 \mathrm{~W} / \mathrm{m}^{2}$ \\
\hline & $\mathrm{T}: 433919 \mathrm{~W} / \mathrm{m}^{2}$ & $\mathrm{~T}: 434619 \mathrm{~W} / \mathrm{m}^{2}$ & $\mathrm{~T}: 435568 \mathrm{~W} / \mathrm{m}^{2}$ & $\mathrm{~T}: 436550 \mathrm{~W} / \mathrm{m}^{2}$ & $\mathrm{~T}: 438231 \mathrm{~W} / \mathrm{m}^{2}$ \\
\hline & $\mathrm{H}: 148881 \mathrm{~W} / \mathrm{m}^{2}$ & $\mathrm{H}: 149843 \mathrm{~W} / \mathrm{m}^{2}$ & $\mathrm{H}: 150906 \mathrm{~W} / \mathrm{m}^{2}$ & $\mathrm{H}: 151892 \mathrm{~W} / \mathrm{m}^{2}$ & $\mathrm{H}: 153201 \mathrm{~W} / \mathrm{m}^{2}$ \\
\hline Azimuth $188^{\circ}$ & $\mathrm{C}: 285388 \mathrm{~W} / \mathrm{m}^{2}$ & $\mathrm{C}: 285049 \mathrm{~W} / \mathrm{m}^{2}$ & $\mathrm{C}: 284936 \mathrm{~W} / \mathrm{m}^{2}$ & $\mathrm{C}: 285016 \mathrm{~W} / \mathrm{m}^{2}$ & $\mathrm{C}: 285388 \mathrm{~W} / \mathrm{m}^{2}$ \\
\hline & $\mathrm{T}: 434269 \mathrm{~W} / \mathrm{m}^{2}$ & $\mathrm{~T}: 434892 \mathrm{~W} / \mathrm{m}^{2}$ & $\mathrm{~T}: 435842 \mathrm{~W} / \mathrm{m}^{2}$ & $\mathrm{~T}: 436908 \mathrm{~W} / \mathrm{m}^{2}$ & $\mathrm{~T}: 438589 \mathrm{~W} / \mathrm{m}^{2}$ \\
\hline & $\mathrm{H}: 149017 \mathrm{~W} / \mathrm{m}^{2}$ & $\mathrm{H}: 149980 \mathrm{~W} / \mathrm{m}^{2}$ & $\mathrm{H}: 151043 \mathrm{~W} / \mathrm{m}^{2}$ & $\mathrm{H}: 152031 \mathrm{~W} / \mathrm{m}^{2}$ & $\mathrm{H}: 153342 \mathrm{~W} / \mathrm{m}^{2}$ \\
\hline Azimuth $189^{\circ}$ & $\mathrm{C}: 285420 \mathrm{~W} / \mathrm{m}^{2}$ & $\mathrm{C}: 285082 \mathrm{~W} / \mathrm{m}^{2}$ & $\mathrm{C}: 284969 \mathrm{~W} / \mathrm{m}^{2}$ & $\mathrm{C}: 285112 \mathrm{~W} / \mathrm{m}^{2}$ & $\mathrm{C}: 285400 \mathrm{~W} / \mathrm{m}^{2}$ \\
\hline & $\mathrm{T}: 434438 \mathrm{~W} / \mathrm{m}^{2}$ & $\mathrm{~T}: 435062 \mathrm{~W} / \mathrm{m}^{2}$ & $\mathrm{~T}: 436012 \mathrm{~W} / \mathrm{m}^{2}$ & $\mathrm{~T}: 437143 \mathrm{~W} / \mathrm{m}^{2}$ & $\mathrm{~T}: 438742 \mathrm{~W} / \mathrm{m}^{2}$ \\
\hline & $\mathrm{H}: 148197 \mathrm{~W} / \mathrm{m}^{2}$ & $\mathrm{H}: 150162 \mathrm{~W} / \mathrm{m}^{2}$ & $\mathrm{H}: 151227 \mathrm{~W} / \mathrm{m}^{2}$ & $\mathrm{H}: 152215 \mathrm{~W} / \mathrm{m}^{2}$ & $\mathrm{H}: 153527 \mathrm{~W} / \mathrm{m}^{2}$ \\
\hline Azimuth $190^{\circ}$ & $\mathrm{C}: 285203 \mathrm{~W} / \mathrm{m}^{2}$ & $\mathrm{C}: 285263 \mathrm{~W} / \mathrm{m}^{2}$ & $\mathrm{C}: 285224 \mathrm{~W} / \mathrm{m}^{2}$ & C: $285292 \mathrm{~W} / \mathrm{m}^{2}$ & $\mathrm{C}: 285504 \mathrm{~W} / \mathrm{m}^{2}$ \\
\hline & $\mathrm{T}: 433400 \mathrm{~W} / \mathrm{m}^{2}$ & $\mathrm{~T}: 435425 \mathrm{~W} / \mathrm{m}^{2}$ & $\mathrm{~T}: 436451 \mathrm{~W} / \mathrm{m}^{2}$ & $\mathrm{~T}: 437507 \mathrm{~W} / \mathrm{m}^{2}$ & $\mathrm{~T}: 439031 \mathrm{~W} / \mathrm{m}^{2}$ \\
\hline
\end{tabular}


Table 7. The calculation of annual total heating, cooling and total energy consumption by incrementing $1^{\circ}$ profile angle between $20^{\circ}$ and $30^{\circ}$ angles found for the optimum orientation angle of $171^{\circ}$ azimuth

\begin{tabular}{|c|c|c|c|c|c|c|}
\hline $\begin{array}{l}\text { Profile Angle } \\
\text { Azimuth Angle }\end{array}$ & $20^{\circ}(44 \mathrm{~cm})$ & $21^{\circ}(46 \mathrm{~cm})$ & $22^{\circ}(48 \mathrm{~cm})$ & $23^{\circ}(51 \mathrm{~cm})$ & $24^{\circ}(53 \mathrm{~cm})$ & $25^{\circ}(56 \mathrm{~cm})$ \\
\hline Azimuth $171^{\circ}$ & $\begin{array}{l}\mathrm{H}: 148892 \mathrm{~W} / \mathrm{m}^{2} \\
\mathrm{C}: 285008 \mathrm{~W} / \mathrm{m}^{2} \\
\mathrm{~T}: 433900 \mathrm{~W} / \mathrm{m}^{2}\end{array}$ & $\begin{array}{l}\mathrm{H}: 148905 \mathrm{~W} / \mathrm{m}^{2} \\
\mathrm{C}: 285018 \mathrm{~W} / \mathrm{m}^{2} \\
\mathrm{~T}: 433923 \mathrm{~W} / \mathrm{m}^{2}\end{array}$ & $\begin{array}{l}\mathrm{H}: 149023 \mathrm{~W} / \mathrm{m}^{2} \\
\mathrm{C}: 284878 \mathrm{~W} / \mathrm{m}^{2} \\
\mathrm{~T}: 433901 \mathrm{~W} / \mathrm{m}^{2}\end{array}$ & $\begin{array}{l}\mathrm{H}: 149069 \mathrm{~W} / \mathrm{m}^{2} \\
\mathrm{C}: 284919 \mathrm{~W} / \mathrm{m}^{2} \\
\mathrm{~T}: 433987 \mathrm{~W} / \mathrm{m}^{2}\end{array}$ & $\begin{array}{l}\mathrm{H}: 149226 \mathrm{~W} / \mathrm{m}^{2} \\
\mathrm{C}: 285063 \mathrm{~W} / \mathrm{m}^{2} \\
\mathrm{~T}: 434290 \mathrm{~W} / \mathrm{m}^{2}\end{array}$ & $\begin{array}{l}\mathrm{H}: 149419 \mathrm{~W} / \mathrm{m}^{2} \\
\mathrm{C}: 284993 \mathrm{~W} / \mathrm{m}^{2} \\
\mathrm{~T}: 434411 \mathrm{~W} / \mathrm{m}^{2}\end{array}$ \\
\hline $\begin{array}{l}\text { Profile Angle } \\
\text { Azimuth Angle }\end{array}$ & $26^{\circ}(59 \mathrm{~cm})$ & $27^{\circ}(61 \mathrm{~cm})$ & $28^{\circ}(64 \mathrm{~cm})$ & $29^{\circ}(67 \mathrm{~cm})$ & $30^{\circ}(69 \mathrm{~cm})$ & \\
\hline Azimuth $171^{\circ}$ & $\begin{array}{l}\mathrm{H}: 149501 \mathrm{~W} / \mathrm{m}^{2} \\
\mathrm{C}: 285067 \mathrm{~W} / \mathrm{m}^{2} \\
\mathrm{~T}: 434568 \mathrm{~W} / \mathrm{m}^{2}\end{array}$ & $\begin{array}{l}\mathrm{H}: 149504 \mathrm{~W} / \mathrm{m}^{2} \\
\mathrm{C}: 285068 \mathrm{~W} / \mathrm{m}^{2} \\
\mathrm{~T}: 434571 \mathrm{~W} / \mathrm{m}^{2}\end{array}$ & $\begin{array}{l}\mathrm{H}: 149559 \mathrm{~W} / \mathrm{m}^{2} \\
\mathrm{C}: 285117 \mathrm{~W} / \mathrm{m}^{2} \\
\mathrm{~T}: 434677 \mathrm{~W} / \mathrm{m}^{2}\end{array}$ & $\begin{array}{l}\mathrm{H}: 149855 \mathrm{~W} / \mathrm{m}^{2} \\
\mathrm{C}: 285142 \mathrm{~W} / \mathrm{m}^{2} \\
\mathrm{~T}: 434997 \mathrm{~W} / \mathrm{m}^{2}\end{array}$ & $\begin{array}{l}\mathrm{H}: 149875 \mathrm{~W} / \mathrm{m}^{2} \\
\mathrm{C}: 285159 \mathrm{~W} / \mathrm{m}^{2} \\
\mathrm{~T}: 435034 \mathrm{~W} / \mathrm{m}^{2}\end{array}$ & \\
\hline
\end{tabular}

Pursuant to the simulation results conducted by incrementing $1^{\circ}$ azimuth angle between $0^{\circ}-40^{\circ}$ profile angle, the optimum orientation angle for $171^{\circ}$ azimuth angle was found between $20^{\circ}-30^{\circ}$ profile angle (Table 6). The results of simulations performed for the calculation of optimum profile angle was given in Table 7 .

In consideration with the simulation results of cube model, the cooling load increases with the increase of profile angle. Consequently, the study conducted for the cube model indicated that the optimum orientation angle is $171^{\circ}$ azimuth and $22^{\circ}$ as optimum profile angle (Table 7).

\section{CONCLUSION}

In this study, the options for building orientation and shading element sizes were identified and the related options were analysed on the cube model. Upon the climate data of Cyprus that the cube model was analysed, the Ecotect simulation program, calculation software for building energy load, was used to analyse the building orientation options and shading element options. The air conditioning systems that are used to provide comfort for indoor users throughout the year comfort use significant amount of energy. The building orientation and sufficiency of shading element are vital factors in the provision of energy consumption and user comfort. When the shading element is used, the orientation and the profile angle of the shading element that are optimum for summers might decrease the indoor thermal comfort through the same shading in winters. Pursuant to the simulation results obtained by Ecotect, the zone with minimum energy consumption was identified as $170^{\circ}$ azimuth, $180^{\circ}$ azimuth and $190^{\circ}$ azimuth orientation. And then the simulations by incrementing $1^{\circ}$ angle reflected that the orientation with total minimum energy (heating + cooling) requirements $171^{\circ}$ azimuth $\left(9^{\circ}\right.$ east from south). In this orientation, when the horizontal shading element is added to the window, minimum total cooling loads occurred between $20^{\circ}$ and $30^{\circ}$ profile angles. As a result of this study, the optimum building orientation for the cube model in Cyprus is determined as $171^{\circ}$ azimuth ( $9^{\circ}$ east from south) and optimum profile angle as $22^{\circ}$.

The study by Zeren, (1987) and Orhon et.al (1988) indicated that the optimum orientation in the warm climate zones is from $3^{\circ}$ southeastornorth and the good orientation intervals as $10^{\circ}$ southwestand $19^{\circ}$ southeast. Pursuant to the simulation results of the cube model, the optimum building orientation with the minimum energy consumption is 9 degrees east from south (azimuth $171^{\circ}$ ). The cube model results were within the optimum orientation zone given in the study by Zeren et.al and the results are consistent. The studies that are separate as building orientation and building shading under the literature are improved with the study conducted for the cube model by adding optimum orientation angle. This study is considered to be useful for the future studies and also education of architecture. Our findings suggest that school buildings can be design toward based on optimum orientation and shading in Mediterranean climate.

The consequences in the building orientation and shading when the materials in the building models change might be studied in the future studies, as well as the changes in the results with the changes in storey height might be another subject for another study. This study conducted in warm climate zones might be performed for different climate zones and the result might be compared. This study would also be beneficial for the researchers in conducting further studies by adding vertical and mesh type shading elements to the horizontal shading element.

\section{REFERENCES}

Akşit, Ş. F. (2002). Soğutma enerjisi korunumunu hedefleyen cephe dokusunun belirlenmesinde kullanılabilecek bir yaklaşım (Doctoral dissertation). İstanbul: İ.T.Ü. Fen Bilimleri Enstitüsü.

Berköz, E. (1973). Güneş radyasyonu etkisinin optimizasyonu açısından binaların yönlendiriliş durumlarının belirlenmesi (Doctoral dissertation). İstanbul: İ.T.Ü.

Berköz, E. (1983). Güneşışınımı ve yapı dizaynı. İstanbul: İstanbul Teknik Üniversitesi Mimarlık Fakültesi. 
Butera, F., D'Orso, A., Farruggia, S., Rizzo, G., \& Silvestrini, G. (1985). Energy conservation in 29 historic school buildings in Palermo. International journal of ambient energy, 6(2), 71-78. doi:10.1080/01430750.1985.9675445

Carlos, J. S. (2017). The impact of refurbished windows on Portuguese old school buildings. Architectural Engineering and Design Management, 13(3), 185-201. doi:10.1080/17452007.2016.1274252

DEU. (2017). Retrieved on 19 October 2017 from http://mimarlik.deu.edu.tr/wpcontent/uploads/2017/04/mimsontr.pdf

Dörter, C. H. (1975). Güneş radyasyonundan yararlanmada binalarda kabuk, yön ve form ilişkisinin araştırılması. Güneş Enerisisi ve Çevre Dizaynı Ulusal Sempozyum, İstanbul: İTÜ Mimarlık Fakültesi.

Elagöz, A. (1989). Enerji korunumlu yapıların yönlendirilmesi ve biçimlendirilmesi için yeni bir metod (Doctoral dissertation). İstanbul: İTÜ Fen Bilimleri Enstitüsü.

Erzen, J. N. (1976). Eğitimin estetik süreç olarak yorumu ve mimarlık eğitimi.

Etzion, Y. (1985). Design of shading devices using a one point method. A technical communication. Energy and buildings, 8(4), 287-290.

Etzion, Y. (1992). An improved solar shading design tool. Building and Environment, 27(3), 297-303.

Givoni, B. (1969). Man, climate and architecture, building research station technion. Israel Institute of Technology, Amsterdam: Elsevier Publishing Company Limited.

Kalfa, S. M. (2014). Türkiye İklim Bölgelerinde Konut Binalar İçin Isıtma ve Soğutma Yüklerinin Belirlenmesinde Kullanılabilecek Bir Yaklaşım. Karadeniz Teknik Üniversitesi, Fen Bilimleri Enstitüsü, Trabzon.

Keleş, N. S, (2016). Gölgeleme elemanlarının bina enerji harcamasına ve kullanıcı konforuna etkisinin değerlendirilmesi. 2. Ulusal yapı fiziği ve çevre kontrolü kongresi, İstanbul: İTÜ Mimarlık Fakültesi.

Koca, Ö. (2015). Sicak kuru ve sıcak nemli iklim bölgelerinde enerji etkin yerleşme ve bina tasarım ilkelerinin belirlenmesine yönelik yaklaşım (Doctoral dissertation). İTÜ Fen Bilimleri Enstitüsü

Lökçe, S. (2002). Mimarlık Eğitim Programları: Mimari Tasarım Ve Teknoloji İle Bütünleşme. Gazi Üniversitesi Mühendislik-Mimarlık Fakültesi Dergisi, 17(3).

Nalçakan, H., \& Polatoğlu, Ç. (2008). Türkiye'deki ve dünyadaki mimarlık eğitiminin karşılaştırmalı analizi ile küreselleşmenin mimarlık eğitimine etkisinin irdelenmesi. Megaron, 3(2).

Neill, S. S. J., \& Denham, E. J. M. (1982). The Effects of Pre-school Building Design. Educational Research, 24(2), 107111. doi:10.1080/0013188820240204

NEU (2017). Retrieved on 19 October 2017 from https://neu.edu.tr/akademik/fakulteler/mimarlikfakultesi/bolumler/mimarlik-bolumu/dersler/?lang=tr

Newman, M., \& Thomas, P. (2008). Student participation in school design: one school's approach to student engagement in the BSF process. Co-Design, 4(4), 237-251. doi:10.1080/15710880802524938

Ok, V. (1983). İklimsel Karaktere Bă̆lı Olarak Optimum Performans Gösteren Yerleşme Yoğunluğunun Belirlenmesinde Geliştirilen Bir Yöntem. İstanbul: İTÜ Mimarlık Fakültesi.

Ok, V. (1992). A procedure for calculating cooling load due to solar radiation: the shading effects from adjacent or nearby buildings. Energy and buildings, 19(1), 11-20.

Olgyay, A., \& Olgyay, V. (1957). Solar control and shading devices. NJ: Princeton Univ Press.

Olgyay, V. (2015). Design with climate: bioclimatic approach to architectural regionalism. NJ: Princeton University Press.

Orhon, I., Küçükdoğu, M. Ş., \& Ok, V. (1988). Doğal İklimlendirme. Toplu Konut İşletmesi Proje Planlama Tasarım El Kitabı. Ankara: TUBITAK YAE.

Orr, K. (2017). Politics and School Buildings: Constructing an Educational Infrastructure for Free Trade New South Wales, 1889-1891. Fabrications, 27(1), 47-70. doi:10.1080/10331867.2016.1262715

Ozay, N., Varoglu, E. S., Aldis, A., Akcay, O., \& Tursoy, B. (2015). Eğitimde ve Pratikte Ortaklıklar ve Sinırlar. Mimarlık ve Eğitim Kurultayı IV, Lefkoşa: KTMMOB Mimarlar Odası.

Ozdeniz, M. B. (2013). Environmental Factors (Climate Design). Note, Graphs and Charts. European University Of Lefke.

Paker Kahvecioğlu, N. (2001). Mimari Tasarım Eğitiminde Bilgi ve Yaratıcılık Etkileşimi (Doctoral dissertation). İTÜ Fen Bilimleri Enstitüsü.

Rogers, R., Atherton, P., Nall, D., \& Greenberg, D. (1978). A Means for including shadowing in a buildings Thermal Analysis, CAD 78. In 3rd International Conference of Computers in Engineering and Building Design, Brighton, UK. 
Shaviv, E. (1978). The Determination of the form of windows and sunshades in a hot climate-a case study. $C A D 78$ proceedings.

Sun, T. Y. (1968). Shadow area equations for window overhangs and side fins and their application in computer calculation. ASHRAE J. (United States), 74.

Türkmenoğlu Bayraktar, N., \& Ok, V. (2011). Gölgeleme araçlarının mekânın toplam soğutma yükleri açısından etkinliklerinin belirlenmesi. İTÜ Dergisi/a, 9(1).

Valko, P. (1973). The Effect of shape and orientation on the radiation impact on building. Teaching the teachers on building climatology CIB colloqium. The National Swedish Institue for Building Research, D20 Stockholm.

Yasar, Y., \& Kalfa, S. M. (2015). The effects of social, cultural and education dynamics on the education-training environment in architectural education; the case study of the department of architecture, KTU. ProcediaSocial and Behavioral Sciences, 182, 408-413.

Yellot, I. J. (1977). Fenestration and heat flow through fenestration, energy conservation through building design.

Yellott, J. I. (1966). Shading coefficients and sun-control capability of single glazing. ASHRAE Trans. (United States), 72.

Yener, A. K. (1996). Pencerelere uygulanan gölgeleme araçlarının tasarımında iklimsel ve görsel konfor koşullarının sağlanması amacıyla kullanılabilecek bir yaklaşım (Doctoral dissertation).

Yüceer, N. S. (2015.). Yapıda çevre ve enerji. Ankara: Nobel yayıncılık.

Yücel, S., \& Aydınlı, S. (2015). Mimarın eğitimi üzerine spekülatif bir deneme/Speculative experiment based on architect's education. Erciyes Üniversitesi Fen Bilimleri Enstitüsü Dergisi, 31(1).

Zeren, L. (1956). Mimaride güneş kontrolü. İstanbul: İTÜ Mimarlık Fakültesi.

Zeren, L. (1962). Radyasyon hesaplayıcıları. İstanbul: İTÜ Mimarlık Fakültesi. Yapı Araştırma Kurumu.

Zeren, L. (1967). Türkiye'nin tipik iklim bölgelerinde en sıcak devre ve en az sıcak devre tayini. İTÜ Mimarlık Fakültesi.

Zeren, L. (1975). Mimarlıkta yapma çevre dizaynı ve güneş enerjisi. İTÜ Mimarlık Fakültesi. Güneş enerjisi ve çevre dizayn ulusal sempozyum bildirisi, İstanbul.

Zeren, L., Berköz, E., Küçükdoğu, M. Ş., \& Yılmaz, Z. (1987). Türkiye'de yeni yerleşmeler ve binalarda enerji tasarrufu amacıyla bir mevzuat modeline iliş̧in çalışma. İstanbul: İTÜ Uyg-Ar Merkezi.

\section{http://www.ejmste.com}

